\title{
THE SANCTORAL CYCLE OF THE PRAGUE SACRAMENTARY
}

\author{
Els Rose \\ Senior Lecturer of Medieval Latin, Utrecht University
}

Prague's Sanctoral Cycle: Context and Characterization

\section{A 'unicum' or a Synthesis?}

In the discussions about the Prague Sacramentary that scholarship has generated so far, the question of whether 'Prague' is a representative of a group of sacramentaries or an idiosyncratic book, even an unicum, is at the centre of attention. ${ }^{1}$ The editors of the sacramentary, Dold and Eizenhöfer, clearly make an effort to clarify the book's relations with contemporary liturgical sources,

1 The bibliography of the Prague Sacramentary is dominated by the elaborate introduction to the edition by Dold and Eizenhöfer and a few articles: Das Prager Sakramentar: Cod. O. 83, fol. 1-120, der Bibliothek des Metropolitankapitels, II: Prolegomena und Textausgabe, ed. by Alban Dold and Leo Eizenhöfer, Texte und Arbeiten, 38-42 (Beuron: Beuroner Kunstverlag, 1949), pp. 1-96; Carl I. Hammer, 'The Social Landscape of the Prague Sacramentary: The Prosopography of an Eighth-Century Mass-Book', Traditio, 54 (1999), 41-80; Carl I. Hammer, 'Recycling Rome and Ravenna: Two Studies in Early-Medieval Reuse', Saeculum, 56 (2005), 295-325; Bernhard Bischoff, Die südostdeutschen Schreibschulen und Bibliotheken in der Karolingerzeit, 2 vols (Wiesbaden: Harrassowitz, 1960-1980), II: Die vorwiegend österreichischen Diözesen, pp. 258-261; Klaus Gamber, 'Das Tassilo-Sakramentar: Das älteste vollständig erhaltene Regensburger Meßbuch', Münchener theologische Zeitschrift, 12 (1961), 205-09; Klaus Gamber, 'Das Sakramentar des Bischofs Arbeo von Freising (764-783)', Münchener theologische Zeitschrift, 9 (1958), 46-54. Cyrille Vogel mentions the book only in the margin of a survey of lectionaries; it is not mentioned in the index of sacramentaries. Cyrille Vogel, Medieval Liturgy: An Introduction to the Sources, trans. by William George Story and Niels Krogh Rasmussen (Washington, DC: Pastoral Press, 1986), p. 345. 
mainly other sacramentaries of the Gregorian, Old Gelasian, and EighthCentury Gelasian traditions. ${ }^{2}$ An attempt to visualize the relations between Prague and the main representatives of these three traditions is reflected in a concordance of all Prague's Mass formularies. ${ }^{3}$ The editors' intention is to identify the most qualified model (or models) to have inspired the composer(s) of the Prague Sacramentary. A different perspective is chosen by Carl Hammer, who emphasizes Prague's idiosyncratic character. Hammer depicts the users of this sacramentary as a group of individuals, living in the periphery (i.e. not under episcopal supervision) and sharing a passionate devotion for St Martin. ${ }^{4}$ Both approaches have resulted in a number of important conclusions and observations, in Hammer's case even in the indication of a specific church 'for which the Sacramentary [of Prague] might have been copied,' 5 wile Dold and Eizenhöfer present the book as a synthesis of existing material and offer a detailed survey of the sources from which Prague may have drawn its material.

The present contribution searches for more clarity about Prague's idiosyncratic position in its liturgical environment through a closer study of its sanctoral cycle. It compares Prague's liturgy of the saints with contemporary liturgical sources of the three traditions mentioned above as well as older traditions in order to specify Prague's Sitz im liturgischen Leben; and it pays particular attention to innovative trends in Prague's sanctoral cycle, more particularly the liturgical cult of those saints in which Prague shows itself innovative with regard to the calendar. ${ }^{6}$

${ }^{2}$ On the early medieval traditions and transmissions of liturgical sources, particularly the sacramentaries, see Vogel, Medieval Liturgy, pp. 61-134; Éric Palazzo, Le Moyen Age: Des origines au XIII eiècle, Histoire des livres liturgiques (Paris: Beauchesne, 1993); trans. A History of Liturgical Books from the Beginning to the Thirteenth Century, trans. by M. Beaumont (Collegeville: Liturgical Press, 1998), pp. 47-83; and briefly, Hammer, 'The Social Landscape', pp. 43-44.

${ }^{3}$ Das Prager Sakramentar, ed. by Dold and Eizenhöfer, pp. 45-48.

${ }^{4}$ Hammer, 'The Social Landscape', pp. 75-76.

${ }^{5}$ Viz. St Martin's in Biberbach. Hammer, 'The Social Landscape', p. 75. Dold and Eizenhöfer hold to Isen as the book's place of origin (Das Prager Sakramentar, ed. by Dold and Eizenhöfer, p. 41).

${ }^{6}$ Despite Hammer's description of the Prague Sacramentary as a conservative book (Hammer, 'The Social Landscape', p. 46), even as an 'outdated and defective article', and 'outdated nearly on the day it was produced' (ibid., p. 76). See on the latter remark also Yitzhak Hen's contribution to this volume, p. 90. 


\section{Prague's Sanctoral Cycle in its Liturgical Context}

The Prague Sacramentary contains about eighty Masses for saints, including, in some cases, preceding vigils and Masses for the octave (the eighth day after the feast proper). As regards the choice of saints, the Prague Sacramentary is comparable to a large number of eighth-century liturgical books, which a modern title indicates as the 'Eighth-Century Gelasian sacramentaries'. Sacramentaries of this kind were produced in Gaul from the mid-eighth century onwards. The oldest preserved manuscript is BNF, MS lat. 12048, called Sacramentarium Gellonense and copied around 790-800. ${ }^{7}$ The model of the Eighth-Century Gelasian sacramentaries, presumably composed and used in the Benedictine monastery of Flavigny during the reign of Pippin III, ${ }^{8}$ obviously replaced the earlier Gallican sacramentaries or books for priests, such as the Missale Gothicum, the Bobbio Missal, and others. They seem to be the result of an early endeavour to create a more uniform liturgy in the Frankish realms and are generally related to Pippin III as the royal patron of a (mainly monastically inspired) movement towards liturgical unity. ${ }^{9}$ Material of the early Gallican sources, some of which go back to the late seventh century, was preserved in the EighthCentury Gelasian sacramentaries. But the books owe their name primarily to their familiarity with the so-called Sacramentarium Gelasianum Vetus, transmitted in a single manuscript (BAV, MS Reg. lat. 316) copied around 750 in the North of Gaul (Chelles), although its exemplar must have been a book with Roman roots. ${ }^{10}$ In the year 795 , Pippin's son Charlemagne received upon his request a Roman sacramentary from Pope Hadrian I, which came to be known as the Sacramentarium Gregorianum Hadrianum. During the decades that followed this event, the Eighth-Century Gelasian sacramentaries played an important role in providing complementary material to the Gregorian Sacramentary, which was necessary because the latter book represented the papal statio-liturgy and was, therefore, hardly suitable to respond to the needs of the daily practice in a Frankish episcopal church or parish community. ${ }^{11}$

${ }^{7}$ Vogel, Medieval Liturgy, p. 71. Vogel lists fourteen representatives of different regions: Frankish Gaul, southern Germany (Bavaria), northern Italy (pp. 71-73). See also Yitzhak Hen, The Royal Patronage of Liturgy in Frankish Gaul to the Death of Charles the Bald (877), HBS, Subsidia, 3 (London: Boydell and Brewer, 2001), pp. 57-61.

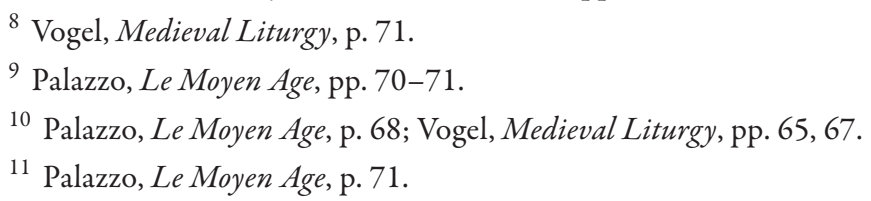


According to Dold and Eizenhöfer, the Prague Sacramentary was modelled on all three traditions mentioned above: the Eighth-Century Gelasian sacramentaries, the Gelasianum Vetus, and the Gregorian tradition. ${ }^{12}$ They base this conclusion on their analysis of, among other things, the relation between Prague's sanctoral cycle and the saints' feasts in the representatives of these traditions. Dold and Eizenhöfer analyse which saints are commemorated in the Gregorian sacramentaries and left out in the Prague Sacramentary, mainly in order to specify and date the particular Gregorian Sacramentary that was used by the compiler(s) of Prague. ${ }^{13}$ Likewise, they discuss the differences between Prague and the Old Gelasian sanctoral cycle. ${ }^{14}$ Dold and Eizenhöfer explain the fact that Prague's sanctoral cycle is less densely populated than is common in the Old Gelasian tradition by pointing to a general character of the Prague Sacramentary that abbreviates its exemplars in all respects. A similar reduction in the calendar of saints is visible in other eighth-century sanctoral cycles, indicated by Dold and Eizenhöfer as 'Auswahlkalendarien.'.

In the present contribution, the Gregorian, Old Gelasian, and EighthCentury Gelasian traditions are chosen for comparison in order to explore what Prague has in common with the surrounding liturgical traditions and, more importantly, to settle Prague's singular characteristics, at least as far as the liturgy of the saints is concerned.

Although Hammer identifies the Prague Sacramentary as a primarily Old Gelasian type of book, ${ }^{16}$ its sanctoral cycle relates it more closely to the EighthCentury Gelasian tradition. Compared to the Frankish eighth-century tradition, Prague counts only one unique saint: Zeno, a rare figure on saints' calendars outside Verona but with a flourishing cult in the region of Bavaria where Prague was composed and used. ${ }^{17}$ Other scholars have considered this Mass for

${ }^{12}$ Das Prager Sakramentar, ed. by Dold and Eizenhöfer, p. 94. See Hammer, 'The Social Landscape', pp. 43-46.

13 Das Prager Sakramentar, ed. by Dold and Eizenhöfer, pp. 61-63.

${ }^{14}$ Das Prager Sakramentar, ed. by Dold and Eizenhöfer, pp. 64-65.

${ }^{15}$ Das Prager Sakramentar, ed. by Dold and Eizenhöfer, p. 65, referring to the sacramentaries of Monza and Rheinau. For a more general comparison between Prague and the Gregorian and Gelasian traditions, see Hammer, 'The Social Landscape', p. 45, who adds the omission of some 'signature saints' feasts' of the Frankish eighth-century Gelasian books (Praeiectus, Conversio Pauli, St Benedict, St Chrysogonus).

${ }^{16}$ Hammer, 'The Social Landscape', p. 45.

17 See Hammer, 'The Social Landscape', p. 65. See also Gamber's discussion of a feast for Zeno in a fragmentary Calendar of Regensburg: Tassilo-Sakramentar, ed. by Klaus Gamber, 'Das Tassilo-Sakramentar in Prague', in Das Bonifatius-Sakramentar und weitere 
Table 1. Saints appearing in Prague's sanctoral cycle, but not found in the Old Gelasian and Gregorian sacramentaries.

\begin{tabular}{ll}
\hline Cathedra Petri & 22 February \\
\hline Translatio Martini & 4 July \\
\hline James the Great, apostle & 25 July \\
\hline Octave feast of Laurence & 17 August \\
\hline Bartholomew, apostle & 25 August \\
\hline Matthew, apostle & 21 September \\
\hline
\end{tabular}

Zeno in the light of the possible place of origin of the Prague Sacramentary. Thus, the presence of this Mass caused Romuald Bauerreiß to locate the sacramentary in the monastery of Isen. ${ }^{18}$

Apart from this one exception, which can be explained by Prague's geographical context, the book commemorates a number of saints that also occur in the Eighth-Century Gelasian sacramentaries but that are absent in the Old Gelasian and Gregorian traditions. These commemorations, which all came into being from the mid-eighth century onwards, clearly outline the calendar innovation in the period in which the Prague Sacramentary was in use.

The saints in question, which are not found in the Old Gelasian or the Gregorian sacramentaries, are listed in Table 1. In the following, the Masses for the saints listed in Table 1 will be discussed in order to examine what they add to our knowledge of the Prague Sacramentary and to a broader understanding of this book and its liturgical and cultural context. The octave for Laurence is left out from this discussion because it is not a new commemoration but an addition to an already existing feast. On the other hand, the natale of St Martin (11 November) is taken into consideration. Although this saint occurs in the Gregorian Sacramentary (but, strikingly, not in the Old Gelasian ${ }^{19}$ ), his commemoration in the Prague Sacramentary is of interest because there are two Mass formularies for 11 November. The second Mass for Martin is deviating

frühe Liturgiebücher aus Regensburg mit vollständigem Facsimile der erhaltenen Blätter, ed. by Klaus Gamber, Textus Patristici et Liturgici, 12 (Regensburg: Pustet, 1975), Appendix I, Das Regensburger Kalendarblatt, pp. 89-92.

${ }^{18}$ Das Prager Sakramentar, ed. by Dold and Eizenhöfer, pp. 37-43.

${ }^{19}$ I have not found any explanation for this remarkable omission; not even in Chavasse's monumental study, who mentions the absence of a Mass for Martin without further comment: Antoine Chavasse, Le sacramentaire gélasien (Vaticanus reginensis latinus 316) (Paris: Desclée, 1958), p. 282. 
from the Gregorian and the Eighth-Century Gelasian traditions, returning instead to the early Gallican sacramentaries from the turn of the seventh to the eighth century. This singular Mass deserves special attention. Since four of the six 'new' saints in the Prague Sacramentary belong to the category of the apostles, it seems fitting to start with them.

\section{The Apostles in Prague's Sanctoral Cycle}

\section{The Liturgical Celebration of the Apostles in the West}

Although the apostles rank highly in the hierarchy of saints, individual feast days were not introduced simultaneously for all twelve. ${ }^{20}$ The oldest Latin martyrology is the Depositio martyrum in the Roman Calendar of Philocalus, dating to the year 354. It is not surprising to find the 'Roman martyrs' Peter and Paul in this list of martyrs. ${ }^{21}$ The early Latin sacramentaries include only a limited number of apostles. Among them we find Peter and Paul as well as James the Great and his brother John the Evangelist, the latter likewise with an early cultplace and near-martyrdom tradition at Rome's Latin Gate. ${ }^{22}$ Finally, Andrew occurs in the earliest sacramentaries and was included in several Western calendars and liturgical books even before his relics reached Italy and Gaul from Constantinople in the second half of the fourth century. ${ }^{23}$ Other apostles, however, were incorporated into the great Latin calendars and sacramentaries only more reluctantly. The cult of Philip and James the Less, for example, commemorated as a pair ever since the dedication of a Roman church to them in the 560s, did not leave a trace in the sacramentaries (Roman or otherwise) until

${ }^{20}$ In the New Testament, various lists of the twelve disciples are given (Mt. 10. 2-4; Mk 3. 16-19; Lk. 6. 14-16; Acts 1. 13). In the Catholic tradition, the following saints came to be considered as the twelve apostles: Peter, Paul, Andrew, John, James the Great, Thomas, Philip, James the Less, Bartholomew, Matthew, Simon, and Jude. Matthias, who replaced Judas Iscariot, is in some cases added to the list.

${ }^{21}$ Depositio martyrum, ed. by Hans Lietzmann, Die drei ältesten Martyrologien (Bonn: Marcus und Weber, 1911), p. 3. See also Michele R. Salzman, On Roman Time: The CodexCalendar of 354 and the Rhythms of Urban Life in Late Antiquity (Berkeley: University of California Press, 1990), pp. 46-47.

22 Tertullian already knew the tradition of John's emersion in a cauldron filled with boiling oil in Rome: Tertullian, De praescriptione hereticorum, ed. by Raymond François Refoulé and P. de Labriolle, in Traité de la prescription contre les hérétiques, SChr, 46 (Paris: Cerf, 1957), c. 36.3 , p. 138.

${ }^{23}$ Missale Gothicum e codice Vaticano Reginensi latino 317 editum, ed. by Els Rose, CCSL, 159D (Turnhout: Brepols, 2005), pp. 262-71. 
the mid-eighth century. ${ }^{24}$ The same goes for Bartholomew, ${ }^{25}$ and for Simon and Jude (the latter two were likewise celebrated as a pair in the Latin tradition). ${ }^{26}$ It took until the end of the eighth century to find sacramentaries (most notably the Eighth-Century Gelasian sacramentaries) that included a full cycle of apostle feasts with individual Mass formularies for all twelve, celebrated individually or in pairs (Peter and Paul, Philip and James, Simon and Jude). The Prague Sacramentary belongs to this late eighth-century generation of sacramentaries, although it deviates from the Frankish Gelasian sacramentaries in its omission of Simon and Jude ( 28 October). There are no deviations in the choice of dates. ${ }^{27}$ Table 2 shows the full list of apostle feasts in the Prague Sacramentary.

Table 2. The apostles in the Prague Sacramentary.

\begin{tabular}{ll}
\hline Iohannes Evangelista & 27 December \\
\hline Cathedra Petri & 22 February \\
\hline Philippus er Iacobus & 1 May \\
\hline Vigilia Petri et Pauli & 28 June \\
\hline Vigilia Petri proprie & 29 June \\
\hline Natale Petri et Pauli & without calendar date (29 June) \\
\hline Natale Pauli proprie & 30 June \\
\hline Octava apostolorum & 6 July \\
\hline Iacobus $[$ Maior $]$ & 25 July \\
\hline Bartholomeus & 25 August \\
\hline Matheus & 21 September \\
\hline Andreas & 30 November (with vigil) \\
\hline Thomas & 21 December \\
\hline
\end{tabular}

${ }^{24}$ Els Rose, Ritual Memory: The Apocryphal Acts and Liturgical Commemoration in the Early Medieval West (c. 500-1215) (Leiden: Brill, 2009), pp. 125-44.

25 Rose, Ritual Memory, p. 81.

${ }^{26}$ Rose, Ritual Memory, p. 216.

27 Only the Liber sacramentorum Augustodunensis has two Masses for Cathedra Petri, namely 18 January and 22 February. Both dates are found on the calendars and in the sacramentaries of early medieval Gaul, perhaps in order to avoid a celebration of this important feast during Lent (Missale Gothicum, ed. by Rose, p. 236-44). Many of the apostle feasts in the Augustodunense are lost due to a large lacuna of three quires between Ascension Day and the end of August. The Liber sacramentorum Engolismensis is the only eighth-century Gelasian sacramentary with a Mass for Peter alone on 29 June. 


\section{Peter and Paul}

The various feasts in commemoration of Peter and Paul included in Prague's sanctoral cycle deserve some remarks. In the first place the Masses for the shared natale of the Principes apostolorum at the end of June are worth noting. Then, the presence of a Mass for Cathedra Petri on 22 February is striking, while it lacks a parallel to the early Gallican sacramentaries' feast of Conversio Pauli (25 January). Prague's feasts in commemoration of Peter and Paul are listed in Table 3.

Table 3. The feasts of Peter and Paul in the Prague Sacramentary.

\begin{tabular}{ll}
\hline Cathedra Petri & 22 February \\
\hline Vigilia Petri et Pauli & 28 June \\
\hline Vigilia Petri proprie & 29 June \\
\hline Natale Petri et Pauli & without calendar date (29 June) \\
\hline Natale Pauli proprie & 30 June \\
\hline Octava apostolorum & 6 July \\
\hline
\end{tabular}

\section{Natale Petri et Pauli: 29 June}

It is no surprise to find the beginnings of a liturgical veneration of the apostles Peter and Paul in Rome. The Mass formularies for the natale of these apostles in the Prague Sacramentary combine Gregorian and Gelasian traditions, which have their origin in Rome. Already in the mid-fourth century, a commemoration of the martyrdom of the two apostles on 29 June is found in the Depositio martyrum, as we have already seen. Why 29 June was chosen as the day of commemoration remains unclear, despite many explorations by both liturgists and archaeologists. ${ }^{28}$ The feast spread to other liturgical regions outside Rome at an early date. It was celebrated in Gaul already in the second half of the fifth century, as is testified by Gregory of Tours. ${ }^{29}$ Peter and Paul were among the

${ }^{28}$ Missale Gothicum, ed. by Rose, pp. 244-48.

29 The date is included in the so-called Calendar of Tours, a list of feasts celebrated in this city during the episcopate of Perpetuus (461-91). Calendar of Tours, in Gregory of Tours, Libri historiarum, X.31, ed. by Bruno Krusch and Wilhelm Levison, MGH, SRM, 1.1 (Hannover: Hahn, 1951), pp. 529-30. 
most favourite patrons in the Frankish realm, where many churches, cathedrals, and monasteries were dedicated to the pair, often in combination with Mary. ${ }^{30}$

In the Prague Sacramentary, the organization of the Masses for the natale Petri et Pauli is a mix of Gregorian and Gelasian traditions. As far as the content of the prayers is concerned, Prague follows mainly the Old Gelasian Sacramentary. Prague differs, however, from the Gelasian tradition in its omission of a separate Mass in commemoration of all apostles (omnium apostolorum), directly following the Masses for Peter and Paul in the Old Gelasian Sacramentary and preceded there by a vigil. ${ }^{31}$

To summarize the liturgical celebration of the natale Petri et Pauli, Prague is more in line with the Old Gelasian tradition than with the Eighth-Century Gelasian tradition. A less unequivocal picture is given by the other feasts for the Principes apostolorum.

\section{Cathedra Petri (22 February) and Conversio Pauli (25 January)}

Apart from the natale Petri et Pauli, the early medieval Latin Churches knew two other important feasts in honour of Peter and Paul: Cathedra Petri and Conversio Pauli. The feast of Peter's Chair (22 February), celebrating Peter's Roman episcopate, is without doubt of Roman origin: it is mentioned on the Calendar of Philocalus dating to the year $354 .{ }^{32}$ For unclear reasons it disappeared from Rome around 600, even before it could leave any traces in the liturgical books. At the time of its disappearance from Rome, or earlier, the feast of Peter's Chair was celebrated in Gaul, where the Calendar of Tours, dating to the second half of the fifth century, testifies to its existence. Almost a century later, the feast is mentioned in the canons of the second Council of Tours (567) as well. ${ }^{33}$ A Mass for Cathedra Petri occurs in most of the Gallican

${ }^{30}$ Eugen Ewig, 'Der Petrus- und Apostelkult im spätrömischen und fränkischen Gallien', Zeitschrift für Kirchengeschichte, 71 (1960), 215-51; repr. in Eugen Ewig. Spätantikes und fränkisches Gallien: Gesammelte Schriften (1952-1973), ed. by Hartmut Atsma (München: Artemis Verlag, 1976-1979), pp. 318-54, at p. 333.

${ }^{31}$ Sacramentarium Gelasianum vetus, ed. by Leo Cunibert Mohlberg, as Liber sacramentorum romanae aeclesiae ordinis anni circuli: Cod. Vat. Reg. lat. 316/Paris Bibl. Nat. 7193, 41/56 (Sacramentarium Gelasianum), Rerum Ecclesiasticarum Documenta, series maior 4 (Rome: Herder, 1968), pp. 147-48.

${ }^{32}$ Depositio martyrum, ed. by Lietzmann, p. 3; Salzman, On Roman Time, p. 47.

33 Calendar of Tours, ed. by Krusch and Levison, p. 530; Council of Tours II (567), in Les canons des conciles mérovingiens (VI $-V I I^{e}$ siècles), ed. by Jean Gaudemet and Brigitte Basdevant, SChr, 354 (Paris: Cerf, 1989), p. 384. 
liturgical books, while it is also present in the Eighth-Century Gelasian sacramentaries. Due to its disappearance from Rome, the feast is lacking in the Old Gelasian and Gregorian books, only to return to Rome after the ninth century, when elements of the Frankish liturgy were transferred to Rome. ${ }^{34}$ In its inclusion of Cathedra Petri the Prague Sacramentary follows the Eighth-Century Gelasian traditions while it differs from the Old Gelasian tradition.

On the other hand, Prague is in accordance with the Gregorian and Old Gelasian Sacramentaries by leaving out the feast of Conversio Pauli, a commemoration that is present in the books of the Eighth-Century Gelasian tradition. Earlier scholars tended to situate the origin of a feast in honour of Paul's conversion in Rome. Louis Duchesne was convinced that the title of the feast referred to a translation of relics, ${ }^{35}$ following the indication in the Martyrologium Hieronymianum: Romae translatio Pauli apostoli. ${ }^{36}$ However, any trace of a celebration of this event is lacking in the books reflecting the liturgical customs of Rome. Rather, the word conversio must be understood to indicate the diverse aspects of Paul's radical change as described in Acts 9. The word translatio could be used for this process as a synonym of conversio. It occurs in the same sense in Jerome's description of Paul's transition from a persecutor to 'a chosen instrument' (Acts 9. 15). ${ }^{37}$ Despite the note in the Martyrologium Hieronymianum, it seems hardly plausible to interpret Conversio Pauli as a Roman feast commemorating a translation of Paul's relics, given the absolute silence about such an event or its liturgical celebration in Rome. The feast must have originated in Gaul, where a Mass is found in the seventh- and early eighth-century sacramentaries, and must have been transmitted from there to Rome in the ninth

${ }^{34}$ Pierre Jounel, Le culte des saints dans les basiliques du Latran et du Vatican au douzième siècle (Rome: École française de Rome, 1977), pp. 225-26; Michele Maccarrone, 'Die Cathedra sancti Petri im Hochmittelalter: Vom Symbol des päpstlichen Amtes zum Kultobjekt', Römische Quartalschrift für christliche Altertumskunde und Kirchengeschichte, 76 (1981), 137-72, at pp. 140-41.

35 Louis Duchesne, La 'Memoria apostolorum' de la via Appia, Atti della Pontificia Accademia Romana di Archeologia (Rome: Pontificia Accademia Romana di Archeologia, 1923), pp. 20-22.

${ }^{36}$ Martyrologium Hieronymianum, ed. by Hippolyte Delehaye and Henri Quentin, Commentarius perpetuus in Martyrologium Hieronymianum, Acta sanctorum quotquot toto orbe coluntur, vel a catholicis scriptoribus celebrantur Novembris II.2 (Brussels: Societas Bollandistarum, 1931), p. 61.

${ }^{37}$ Jerome, De viris illustribus, ed. by Carl Albrecht Bernoulli, Der Schriftstellerkatalog des Hieronymus ein Beitrag zur Geschichte der altchristlichen Literatur (Frankfurt: Minerva, 1968), c. 5, p. 9. See Missale Gothicum, ed. by Rose, pp. 233-34. 
century. The copy of the Sacramentarium Gregorianum sent to Charlemagne in the last decade of the eighth century did not include a Mass for this feast; it was added in the Supplement $(810-15)$ attributed to Benedict of Aniane. ${ }^{38}$

The observations concerning the treatment of the different liturgical feasts in honour of Peter and Paul in the Prague Sacramentary make clear that it is not always possible to indicate which tradition (Old Gelasian, Gregorian, or Eighth-Century Gelasian) has been decisive for the composer(s) of the book. A fairly eclectic use of particularly the Old Gelasian and the Eighth-Century Gelasian traditions is visible. And what role did the earlier Gallican sacramentaries play? The discussion of the Masses for St Martin below will elucidate the latter's contribution further. But first the other apostles remain to be discussed.

\section{The Other Apostles and the Relation with the Narrative Virtutes apostolorum}

The inclusion of individual feasts for all twelve apostles is an important innovative element in the liturgical commemoration of the Frankish, German, and Italian churches in the late eighth and early ninth centuries. ${ }^{39}$ The Gregorian and the Old Gelasian sacramentaries do not offer an individual Mass for all twelve apostles. The inclusion of Masses for eleven apostles in the Prague Sacramentary not only is paralleled by the occurrence of these feasts in the Eighth-Century Gelasian sacramentaries, but it must also be linked to the renewed interest in the narrative traditions surrounding the apostles in the early medieval West. A series of texts relating the 'Acts' of the apostles in Latin was copied in a considerable number of manuscripts from the mid-eighth century onwards. The texts belonging to this series are partly adaptations of the Greek apocryphal Acts of the Apostles and partly new compositions that seem to take their origin in the sixth century. Ever since Wolfgang Lazius's edition

38 Le sacramentaire grégorien: ses principales formes d'après les plus anciens manuscrits, ed. by Jean Deshusses, 3 vols, Spicilegium Friburgense, 16, 24, and 18 (Fribourg: Éditions universitaires Fribourg Suisse, 1979-82), I, 503; see on this Supplement Vogel, Medieval Liturgy, pp. 102-04.

39 The most important liturgical source of early medieval Spain, Liber Mozarabicus sacramentorum, adds commemorations for all apostles. This manuscript is generally dated to the tenth century, but part of its Masses may date to the seventh century. Fernand Cabrol, 'Mozarabe (la liturgie)', in Dictionnaire d'archéologie chrétienne et de liturgie, XII (Paris: Letouzey et Ané, 1935), cols 390-491, at col. 407; see Archdale A. King, Liturgies of the Primatial Sees (London: Longmans, Green, 1957), p. 486. 
of this series in 1551, it has been known under the title "The Collection of Pseudo-Abdias. ${ }^{40}$ The attribution to Abdias, however, must be dismissed as a misinterpretation of the coherence of the individual texts. In the following, I will use the term 'Virtutes apostolorum'. ${ }^{41}$

From the ninth century onwards, the Virtutes apostolorum were transmitted as a coherent entity, even though the sections on individual apostles were also copied separately. A survey of the manuscripts transmitting the series as a whole makes clear that Bavaria was an important region of copying. Many of the oldest known manuscripts find their origin in this area, either in Salzburg (ÖNB, MS 534, s. IX) or in the monastery St Emmeram in Regensburg (Dublin, Trinity College, MS 737, s. IX). Another manuscript from St Emmeram, a de luxe passionary dating to the twelfth century that starts with the Virtutes apostolorum, indicates that the interest in the Virtutes apostolorum did not disappear from St Emmeram after the ninth century. ${ }^{42}$ Parallel to the Bavarian transmission of the Virtutes apostolorum, manuscripts from the mid-eighth century onwards testify to a similar tradition in Frankish scriptoria. ${ }^{43}$ Though it is difficult to decide where the tradition of the Virtutes apostolorum in a coherent series originated, the direction was possibly from Frankish Gaul to Bavaria, perhaps via the insular world. ${ }^{44}$ There is also proof of an exchange between Bavarian manuscripts and Frankish centres, for instance through the eleventh-century manuscript from St Thierry, Rheims, copied from (the same exemplar as) the ninth-century Regensburg codex (Dublin, TC, MS 737) and later adapted to local needs. ${ }^{45}$

40 See Els Rose, 'Abdias scriptor vitarum sanctorum apostolorum? The "Collection of Pseudo-Abdias” Reconsidered', Revue d'histoire des textes, n.s. 8 (2013), 227-68.

${ }^{41}$ Guy Philippart gives a list of titles occurring in the manuscripts: Guy Philippart, Les légendiers latins et autres manuscrits hagiographiques, Typologie des sources du Moyen Âge latin, 24-25 (Turnhout: Brepols, 1977), p. 88. I use the term Virtutes apostolorum, in harmony with most recent research, e.g. Acta Iohannis, ed. by Éric Junod and Jean-Daniel Kaestli, 2 vols, CCSA, 1-2 (Turnhout: Brepols, 1983); Maurice Geerard, Clavis apocryphorum Novi Testamenti (Turnhout: Brepols, 1992), pp. 158-59, no. 256.

42 Bamberg, Staatsbibliothek, Msc. Hist., 139 (s. XII).

43 See Els Rose, 'Virtutes apostolorum: Editorial Problems and Principles', Apocrypha, 23 (2012), 11-45.

${ }^{44}$ As hypothesized in Els Rose, 'Virtutes apostolorum: Origin, Aim, and Use', Traditio, 68 (2013), 57-96.

45 See Acta Iohannis, ed. by Junod and Kaestli, II, 756; François Dolbeau, 'Typologie et formation des collections hagiographiques d'après les recueils de l'abbaye de Saint-Thierry', in Saint-Thierry: Une abbaye du vie au XX $X^{e}$ siècle, ed. by Michel Bur (Saint-Thierry: Association des Amis de l'Abbaye de Saint-Thierry, 1979), pp. 159-82, at p. 164. See Maarten Prot, 'Textual 
The Prague Sacramentary clearly reflects this increasing interest in and cult of the apostles. It includes an individual Mass for all apostles apart from Simon and Jude on 28 October. ${ }^{46}$ Masses for John the Evangelist (27 December), Philip and James (1 May), Andrew (30 November, with a vigil) were common in both the Gregorian and Old Gelasian traditions, while a Mass in commemoration of Thomas (21 December) is present in the Old Gelasian Sacramentary but absent from the early Gregorian tradition. In addition, there are three 'new' apostle feasts: James the Great (25 July), Bartholomew (25 August) and Matthew (21 September). This is illustrated in Table 4.

Table 4. The other apostles in the Prague Sacramentary.

\begin{tabular}{ll}
\hline Iohannis Evangelista & 27 December \\
\hline Philippus ङ Iacobus & 1 May \\
\hline Iacobus $[$ Maior $]$ & 25 July \\
\hline Bartholomeus & 25 August \\
\hline Matheus & 21 September \\
\hline Andreas & 30 November (with vigil) \\
\hline Thomas & 21 December \\
\hline
\end{tabular}

The liturgical commemoration of James the Greater on 25 July was a relatively recent development in the western calendars of saints. The Eighth-Century Gelasian sacramentaries seem to be the first to celebrate the son of Zebedee on this date. In earlier sacramentaries belonging to the Old Gallican, Old Spanish, North African, and Milanese rites, James was commemorated in the Octave of Christmas, near to his brother John (the Evangelist) and the Holy Innocents. ${ }^{47}$ In Rome, a commemoration of James the Greater was introduced into the sacramentaries only after the Frankish liturgical books became influential in the papal city, so from the ninth century onwards. ${ }^{48}$ The choice for 29 December

Variety and the Linguistic Context of the Virtutes apostolorum' (unpublished doctoral thesis, Utrecht University, 2013), pp. 165-78.

46 This omission is difficult to explain. The manuscript does not show any lacunas in the environment of the place where this Mass would be expected. Dold and Eizenhöfer signal the omission without giving any explanation; Das Prager Sakramentar, ed. by Dold and Eizenhöfer, p. 65 .

${ }^{47}$ Missale Gothicum, ed. by Rose, pp. 206-08.

${ }^{48}$ His feast is lacking in the Gregorian and Old Gelasian sacramentaries. 
to commemorate James the Greater can probably be explained by the influence of the fifth-century Calendar of Jerusalem and contemporary calendars from Asia Minor, where James was celebrated in the week after Christmas. ${ }^{49}$ The date of 25 July, however, is less easily explained. It occurs for the first time in the Martyrologium Hieronymianum, ${ }^{50}$ and then in medieval liturgical books. ${ }^{51}$

The commemoration of Bartholomew on 25 August is a comparatively late development in the West, where a Mass is found only from the second half of the eighth century onwards. The Eighth-Century Gelasian sacramentaries are the earliest manuscripts that include this commemoration. ${ }^{52}$ The Prague Sacramentary is one of the earliest surviving manuscripts containing a Mass for Bartholomew.

The case of Matthew is different. The Old Gelasian and the Gregorian sacramentaries do not include a Mass for this apostle, in spite of the Roman church dedicated to him at the end of the fifth century. ${ }^{53}$ A Mass for Matthew is, however, included in one of the earliest Gallican sacramentaries, namely the so-called Irish Palimpsest Sacramentary. ${ }^{54}$ This seventh-century manuscript is of mixed Irish and continental origin, written on the continent in a monas-

49 On the relations between the liturgy of Jerusalem on the one hand and early medieval Spain and Gaul on the other, see Anton Baumstark, Liturgie comparée: Principes et méthodes pour l'étude historique des liturgies chrétiennes, $3 \mathrm{rd}$ edn (Chevetogne: Éditions de Chevetogne, 1953); Anton Baumstark, 'Orientalisches in altspanischer Liturgie', Oriens christianus, 32 (1935), 1-37, at pp. 15-18; Marie-Émile Boismard, Le martyre de Jean l’apôtre, Cahiers de la Revue biblique, 35 (Paris: Gabalda, 1996), pp. 34-36. See further on James's feast in the Christmas Octave, Missale Gothicum, ed. by Rose, p. 206.

50 Martyrologium Hieronymianum, ed. by Delehaye and Quentin, p. 395.

${ }^{51}$ Kellner mentions a relic translation, without getting into any detail. Karl A. H. Kellner, Heortologie oder die geschichtliche Entwicklung des Kirchenjahres und der Heiligenfeste von den ältesten Zeiten bis zur Gegenwart (Freiburg im Breisgau: Herder, 1911), p. 220. But see note 63 below.

52 The Liber Mozarabicus sacramentorum likewise includes a Mass for Bartholomew in August, but it is difficult to date this Mass more precisely than 'between the seventh and the tenth century'.

53 Christian Huelsen, Le chiese di Roma nel medio evo: Cataloghi ed appunti (Firenze: Olschki, 1927), pp. 124 and 386-87; Pierre Jounel, 'Le culte des apôtres à Rome et dans la liturgie romaine', in Saints et sainteté dans la liturgie, ed. by Achille M Triacca, Conférences Saint-Serge 1986 (Rome: Edizione liturgiche, 1987), pp. 167-87, at p. 171.

${ }^{54}$ Irish Palimpsest Sacramentary, ed. by Alban Dold and Leo Eizenhöfer, Das irische Palimpsestsakramentar im CLM 14429 der Staatsbibliothek München (Beuron in Hohenzollern: Beuroner Kunstverlag, 1964), pp. 145-50. 
tery of Irish foundation or, as others suggest, in Northumbria, by a scribe with an Irish background. ${ }^{55}$ Despite the uncertainty surrounding its origins, the Irish Palimpsest Sacramentary is generally considered to be 'the most Gallican Sacramentary', as well as the earliest source giving insight into the liturgy as celebrated in Merovingian Gaul. ${ }^{56}$ It is in any case the oldest manuscript containing a Mass in celebration of Matthew. Then follow the Eighth-Century Gelasian sacramentaries, with which Prague shares its Mass for Matthew.

Despite the clear parallel between the increasing liturgical interest in the apostles reflected by the Prague Sacramentary on the one hand, and on the other the expanding activity with regard to the transmission of the narrative Virtutes apostolorum at the same time and in the same region of Prague's compilation and use, it must be said that the influence of the legendary narratives on the liturgical texts in the Prague Sacramentary is very modest. The prayers that fill the apostle Masses in Prague concentrate on the ritual of the Eucharist rather than on the hagiographic detail of the commemorated apostles. In this respect, Prague is entirely in line with the sacramentaries of the Gregorian, Old Gelasian, and Eighth-Century Gelasian traditions, with their reluctant attitude towards the narrative component of liturgical prayers, while it deviates from the older (Old Spanish and Gallican) traditions as well as from later local traditions, for example, the Beneventan Mass books of the eleventh century. While the Old Gallican Irish Palimpsest Sacramentary (Matthew), the Old Spanish Liber Mozarabicus Sacramentorum (all individual apostles), and the eleventhcentury Beneventan Canosa Missal (Bartholomew) incorporate many details found in the Virtutes apostolorum, the prayers in Prague show little interest in the stories about the apostles' lives and martyrdom. They focus instead on traditional apostolic qualities. The following examples may illustrate this. ${ }^{57}$

\section{Praedicator et doctor}

The first traditional quality of an apostle is his activity as a missionary of the faith. The theme is present in many sections of the Virtutes apostolorum, where the apostles are portrayed as preachers and teachers. The theme occurs in the

55 Yitzhak Hen, 'Rome, Anglo-Saxon England, and the Formation of the Frankish Liturgy', Revue Bénédictine, 112 (2002), 301-22, at pp. 312-13.

56 Hen, 'Rome, Anglo-Saxon England', p. 312.

${ }^{57}$ For further reading on the influence of the Virtutes apostolorum on the liturgy of the apostles in the medieval West, see Rose, Ritual Memory, pp. 178-84 (on Matthew in the Irish Palimpsest Sacramentary); pp. 100-101 (on Bartholomew in the Beneventan Canosa Missal), passim on the Liber Mozarabicus Sacramentorum. 
prayers of Prague in a rather general way. This is clear from the following example, found in the Mass for Bartholomew in the Prague Sacramentary. It is not a prayer specific for Bartholomew, since it is found in other sacramentaries in the Mass for John the Evangelist (Sacramentarium Veronense; Missale Gothicum). ${ }^{58}$

Omnipotens sempiterne deus qui huius diei ueneranda $<\mathrm{m}>$ sanctamque laetitiam beati apostoli tui Bartholomei festiuitate tribuisti, da aecclesiae tuae quaesumus amare quod credidit et praedicare quod docuit. Per [...].59

[Almighty and eternal God, who has given the honourable and holy joy of this day through the feast of your blessed apostle Bartholomew, grant your church, we beseech you, to love what he believed in, and to preach what he taught. Through [our Lord...].]

The Virtutes apostolorum are important sources of the content of the apostolic preaching and doctrine, ${ }^{60}$ but the liturgical prayers in Prague only refer to the mere fact that the apostles preached and taught, without going into detail.

\section{Supplicator et praedicator}

A second core quality of an apostle is his intercession. This intermediary function is obviously attributed to every saint, but the prayers of the apostles were believed to be extra powerful because of their proximity to Christ as eyewitnesses and followers of the latter's passion in martyrdom. The following example is taken from the Mass for Matthew in the Prague Sacramentary, where the apostle's preaching and intercession are combined:

SECRETA Supplicationibus nostris apostolicis beati Mathei euangelistae, quaesumus, aecclesiae tuae commendetur oblatio, cuius magnificasti [magnificis] praedicationibus eruditur. Per [...]. ${ }^{61}$

[May the sacrifice of your Church, we beseech you, be recommended by the apostolic prayers of our blessed evangelist Matthew, through whose magnificent preaching she receives her education. Through [our Lord...].]

58 Sacramentarium Veronense, ed. by Leo Cunibert Mohlberg (Rome: Herder, 1994), p. 163; Missale Gothicum, ed. by Rose, 322, p. 474.

59 Prague, Archiv Pražského hradu, MS O. 83, fol. 67 ; Das Prager Sakramentar, ed. by Dold and Eizenhöfer, p. 100.

${ }^{60}$ See also Els Rose, 'De apostelen als leermeesters in het geloof', in Middeleeuwse magister, ed. by Mariken Teeuwen and Els Rose (Hilversum: Verloren, 2008), pp. 79-97.

${ }^{61}$ Prague, Archiv Pražského hradu, MS O. 83, fol. 70; Das Prager Sakramentar, ed. by Dold and Eizenhöfer, p. 105. 


\section{Martyr or Non-martyr?}

A third quality is martyrdom, traditionally attributed to almost all apostles. The following example is from the Mass for James the Greater in the Prague Sacramentary (25 July):

SUPER OBLATA Oblationes populi tui domine quaesumus beati apostoli tui Iacobi passio beata $[e]$ conciliet, et quae nostris $<$ non $>$ apta sunt meritis fiant tibi placita eius deprecatione. Per $\left[\ldots . .{ }^{62}\right.$

[May the blessed passion of your holy apostle James recommend the offerings of your people, we beseech you o Lord, and may those [offerings] that through our merits are not appropriate, become pleasing to you through his prayer. Through [our Lord...].]

In this prayer, the focus is not on the particularities of the apostle's passion, ${ }^{63}$ but on the effectiveness of the Eucharistic ritual, enhanced because of its performance in commemoration of James's martyrdom.

We see that on the whole Prague is reluctant in its depiction of detailed images of the apostles, focusing instead on characteristics generally attributed to all apostles, and not on the hagiographic details as narrated in the Virtutes apostolorum. However, there might be one exception: Philip's martyrdom. In the Latin narrative tradition, there are two apostles who did not suffer martyrdom but died a peaceful death. John the Evangelist escaped the cauldron of boiling oil and stepped into his grave to enter the sleep of death. Moreover, in the Latin tradition Philip is attributed a peaceful death as well, despite the existence of a Greek Martyrion Philippi, added to the fifth-century Greek Acta Philippi. ${ }^{64}$ However, the tradition of Philip's martyrdom through crucifixion

62 Prague, Archiv Pražského hradu, MS O. 83, fol. 62 ${ }^{\text {r }}$; Das Prager Sakramentar, ed. by Dold and Eizenhöfer, p. 92.

63 James is the first apostle who suffered martyrdom (Acts 12.2). According to the Virtutes apostolorum, he preached in Judea and Samaria, and in Jerusalem. He was brought to Herod by the High Priest and some scribes and Pharisees and beheaded. See Ecrits apocryphes chrétiens, II, ed. by Pierre Geoltrain and Jean-Daniel Kaestli (Paris: Gallimard, 2005), pp. 771-88. According to James of Voragine, the apostle James went to Spain first but made few disciples there. He returned with some of them to Judea where he was beheaded on Herod's command, on 25 March, the feast of the Lord's annunciation as James of Voragine adds. His body was transferred to Spain (Compostela) on 25 July.

${ }^{64}$ On the ambiguous tradition of Philip's death and the liturgical commemoration of this apostle as a martyr or not, see Rose, Ritual Memory, pp. 125-61 and 279-86. On the Greek apocryphal Acts of Philip, see Actes de l'apôtre Philippe: Introduction, notes et traductions, ed. by 
and stoning was known as well in the West from an early date. ${ }^{65}$ In fact, there are few Latin liturgical traditions that do not treat Philip as a martyr, if only because his companionship with James forbids this. Philip shared a church in Rome with James in the late sixth century, housing both apostles' relics. ${ }^{66}$ The following prayer in the Prague Sacramentary, however, seems to walk a different path:

Deus qui es omnium sanctorum tuorum splendor mirabilis qui $[\mathrm{c}] \mathrm{que}^{67}$ hunc diem beatorum apostulorum Philippi et Iacobi mysteria consecrasti, da aecclesiae tuae natalitia tantae festiuitatis laetare, ${ }^{68}$ ut aput misericordiam tuam exemplis eorum $<$ et $>$ meritis adiuuemur. Per $[\ldots]{ }^{69}$

[God, wondrous splendour of all your saints, who has consecrated this day by the mystery of your blessed apostles Philip and James, grant your Church that she may rejoice in the anniversary of such a great feast, so that she may be helped through your mercy by their examples and merits. Through [our Lord...].]

The misheard relative pronoun + coordinating conjunction (qui que), represented erroneously by quicque so that the structure of the sentence is obscured, is not the largest linguistic problem in this text. The word mysteria is emended

François Bovon, Bertrand Bouvier, and Frédéric Amsler, Apocryphes: Collection de poche de l'AELAC, 8 (Turnhout: Brepols, 1996), pp. 25-80; François Bovon, 'Les Actes de Philippe', in Wolfgang Haase and others, Aufstieg und Niedergang der römischen Welt, II.25.6 (Berlin: De Gruyter, 1988), pp. 4475-4521.

${ }^{65}$ See Breviarium apostolorum, ed. by Alexandre Dumas and Jean Deshusses, in Liber sacramentorum Gellonensis, CCSL, 159 (Turnhout: Brepols, 1981), pp. 489-90. This brief list of data concerning the apostles' mission and martyrdom is dated to around 600 and transmitted from the eighth century onwards. Baudouin De Gaiffier, 'Le Breviarium apostolorum (BHL 652): Tradition manuscrite et oeuvres apparantées', Analecta Bollandiana, 81 (1963), 89-116, at pp. 92-94 and 113-15.

${ }^{66}$ Liber pontificalis, ed. by Louis Duchesne (Paris: De Boccard, 1955-1957), c. LXII.3 and LXIII.1, pp. 303 and 305. See Huelsen, Le chiese di Roma, pp. 201-02, and Herman A. A. P. Geertman, More veterum: Il Liber Pontificalis, e gli edifici ecclesiastici di Roma nella tarda antichità e nell'alto medioevo (Groningen: Tjeenk Willink, 1975), p. 134 and passim.

${ }^{67}$ quicque pro qui que, as is found in the Old Gelasian and Eighth-Century Gelasian sacramentaries (see Sacramentarium Gelasianum, ed. by Mohlberg, p. 137); the scribe probably misheard the combination of these words when the text was read aloud to him.

${ }^{68}$ Corrected to laetari by Dold and Eizenhöfer, but both forms occur. Charlton T. Lewis and Charles Short, A Latin Dictionary (Oxford: Oxford University Press, 1998), s.v.

${ }^{69}$ Prague, Archiv Pražského hradu, MS O. 83, fol. 48 ; Das Prager Sakramentar, ed. by Dold and Eizenhöfer, p. 70. 
by Dold and Eizenhöfer in their edition of the Prague Sacramentary, replacing mysteria by martyrio and, by doing so, following the version of this prayer in the Eighth-Century Gelasian sacramentaries. ${ }^{70}$ However, in the case of the apostle Philip this is not necessarily the correct solution. Apart from the contested word mysteria, the three prayers of this Mass do not refer to a martyrdom of either Philip or James. Could it be that the composers of Prague, perhaps already possessing a copy of the Virtutes apostolorum, deliberately altered the word martyrio and chose mysteria (incorrectly for mysteriis or mysterio or, perhaps, ministeriis/ministerio), ${ }^{71}$ to express the apostles' liturgical veneration rather than their (partly contested) martyrdom? ${ }^{72}$

Summarizing, we can conclude that the Prague Sacramentary belongs to a new generation of liturgical books, being one of its oldest representatives, which included new commemorations in its sanctoral cycle in order to complete the series of apostle feasts (the lack of a feast in honour of Simon and Jude is and remains remarkable). The Prague Sacramentary focuses on general characteristics of the apostles with little attention to hagiographic details - with Philip as the only possible exception. A different picture emerges from the last saint in Prague's sanctoral cycle to be discussed here: Martin of Tours.

\section{Martin of Tours: natale and translatio}

St Martin of Tours is honoured in the Prague Sacramentary with three Masses: two for his natale (11 November) and one for the commemoration of the translation of his relics (4 July). The presence of a commemoration of this saint in the Prague Sacramentary is in itself not surprising. Martin, one of the favourite saints of western Christendom, has Masses in the early Gallican Mass books, as well as the Gregorian and the Eighth-Century Gelasian sacramentaries - the lack of a Mass in honour of this great saint in the Old Gelasian Sacramentary

70 Breviarium apostolorum, ed. by Dumas and Deshusses, p. 125; Sacramentarium Gelasianum, ed. by Mohlberg, 860, p. 137; Liber sacramentorum Engolismensis, ed. by Patrick Saint-Roch, CCSL, 159C (Turnhout: Brepols, 1987), 938, p. 138; Sacramentarium Sangallense, ed. by Leo Cunibert Mohlberg, Das fränkische Sakramentarium Gelasianum in alamannischer Überlieferung (Codex Sangall, No 348) (Münster: Aschendorff, 1939), 732, p. 112. The prayer does not occur in the Sacramentaries of Monza, Salzburg, or Arno.

${ }^{71}$ It is also possible that the neuter noun, occurring so often in the plural, was considered to be of the first declension. See Missale Gothicum, ed. by Rose, pp. 68-69.

72 See for the variety of meanings of the word mysterium Albert Blaise, Dictionnaire latinfrançais des auteurs chrétiens (Turnhout: Brepols, 1954), s.v. 
(see above, note 19) is a striking and as yet unsolved problem. Prague is, however, singular among its contemporaries in many respects as far as the veneration of Martin is concerned. It is unique in the first place because of its inclusion of the Gregorian Mass as the first Mass for Martin's natale on 11 November, which is not found in any of the Eighth-Century Gelasian sacramentaries. The Gregorian Mass consists of three short prayers, most probably dated to the final quarter of the seventh century. These prayers are general prayers to honour saints and are found in other Gregorian Masses for martyrs ${ }^{73}$ - the fact that prayers to honour a martyr are deemed fit to celebrate the confessor Martin is interesting in itself. There is, however, little specific material related to the life of Martin in these texts.

Prague is also distinctive because of the other Mass for Martin's natale. This is a compilation based on older Gallican sources, most notably the Gothic Missal and, to a lesser extent, the Bobbio Missal. The most striking element is the so-called contestatio, the Old Gallican part of the Eucharistic prayer that preceded the Sanctus and changed daily to focus on the day's proper character. The Eighth-Century Gelasian sacramentaries include the same text in their Mass for 11 November but in an adapted version (both shortened and, as far as language is concerned, corrected $\mathrm{d}^{74}$ ), while Prague is close to the version in the Old Gallican sacramentaries. Because of its linguistic features, the prayer will be discussed more elaborately in the following section.

In the third place, the Prague Sacramentary is almost unique for its inclusion of a Mass to celebrate 4 July, the day of translation of Martin's relics. In the late fifth century, a new basilica was built in Tours by its bishop Perpetuus (461-91), in order to house the relics of St Martin and to host the multitude of pilgrims visiting this important shrine. ${ }^{75}$ The church was dedicated on 4 July, the day of Martin's episcopal consecration. The commemoration of dedication and translation, celebrated in Tours as a feast day from the late fifth century onwards,$^{76}$ was not widely received in the early medieval sacramentaries. Only few books before the ninth century mention it, among them the Prague

73 Guy Marie Oury, 'Les messes de Saint Martin dans les sacramentaires gallicans, romanofrancs et milanais', Études grégoriennes, 5 (1961), 73-97, at p. 79.

${ }^{74}$ The Mass is found in the Eighth-Century Gelasian sacramentaries of Gellône, Angoulême, and Autun (Frankish Gaul); of Sankt Gallen and of Arno (Bavaria, Salzburg); and of Monza (northern Italy).

${ }^{75}$ Calendar of Tours, ed. by Krusch and Levison, pp. 529-30.

76 The date is present on the Calendar of Tours, ed. by Krusch and Levison, pp. 529-30. 
Sacramentary. The feast as such is found in other Bavarian liturgical sources of the eighth century, ${ }^{77}$ but a parallel to the Mass in Prague is sought for in vain.

The Mass in Prague consists of three short prayers, collected from different (Old) Gelasian books. The prayers are of general character, referring to the solemnia or solemnitas celebrated in honour of the confessor and Bishop Martin, but without any specific references to the saint's vita. The set of prayers is in no way comparable to the Mass for 4 July in the contemporary Eighth-Century Gelasian Sacramentary of Angouleme, which consists of six long prayers, all referring to hagiographical details concerning Martin's episcopate in Tours, the building of the new cathedral in this city, and the transfer of the saint's relics to this new basilica. ${ }^{78}$ The latter event is described in detail by Gregory of Tours in his Libri IV de virtutibus sancti Martini. ${ }^{79}$

Although the presence of a Mass in die translationis confessoris sancti Martini in the Prague Sacramentary is an indication of a special veneration of the great Frankish saint, the Mass itself is in harmony with Prague's general abbreviating character and stands apart from contemporary formularies for this feast.

\section{Linguistic Features}

The second Mass in natale sancti Martini offers an interesting insight into Prague's peculiar linguistic profile. The larger part of this Mass follows the one for Martin's feast day as it occurs in the Old Gallican Missale Gothicum, or Gothic Missal. This Burgundian book, transmitted in a singular manuscript dating to the last decade of the seventh or the first decade of the eighth century, was written in a scriptorium where the script of Luxeuil was current and was used presumably in a cathedral church, most probably that of Autun. ${ }^{80}$

77 See Hammer, 'The Social Landscape', p. 66, who mentions an early eighth-century Old Gelasian sacramentary calendar from Regensburg, with reference to Petrus Siffrin, 'Das Walderdorffer Kalenderfragment Saec. viII und die Berliner Blätter eines Sakramentars aus Regensburg', Ephemerides Liturgicae, 47 (1933), 201-24, at p. 204. Likewise the feast is found in later sacramentaries from Regensburg as indicated by Gamber, 'Das Tassilo-Sakramentar in Prague', p. 14.

${ }^{78}$ Liber sacramentorum Engolismensis, ed. by Saint-Roch, 1100-05, pp. 163-64. Saint Roch indicates the episcopal church of Angoulême as the place where this book was used (ibid, pp. viii-ix and xiii).

${ }^{79}$ Gregory of Tours, Libri IV de virtutibus sancti Martini episcopi, ed. by Bruno Krusch, in Miracula et opera minora, MGH, SRM, 1.2 (Hannover: Hahn, 1885), pp. 591-92.

${ }^{80}$ For further introduction, see Missale Gothicum, ed. by Rose, pp. 11-17. 
Table 5. The contestatio Qui sancti spiritus tui dono succensus in the Prague Sacramentary and the Gothic Missal.

\section{Prague Sacramentary, fol. $74 r-v$}

CONTESTATIO ${ }^{1}$ Vere dignum nos te $^{2}$ domine deus noster, in laudibus sancti ${ }^{3}$ Martini hono/rare

qui sancto spiritu ${ }^{4}$ dono succensus est, ita $\mathrm{ut}^{5}$ in ipso / tyrocinio fidei inuentus est,

ut Christum texisset in / pauperem, ${ }^{6}$ ut $^{7}$ uestem quam ${ }^{8}$ egenus ${ }^{9}$ acciperet $/$ mundi dominum ${ }^{10}$ induisset.

O felix ${ }^{11}$ largitas / [fol. 74v] qua diuinitas operetur.

O clamidis ${ }^{12}$ gloriosa / diuisio quae ${ }^{13}$ militem texit et regem. Inaestimabile / domum ${ }^{14}$ est, quod uestire $<$ deum $>$ meruit deitatis.

Dignae $^{15} /$ huic confessionis tuae praemium comisisti,

dignia / regionum ${ }^{16}$ non subiacuit ferritate, ${ }^{17}$

dignae $^{18}$ tanto / amore Martinus persecutoris tormenta non ti/muit saecuribus. ${ }^{19}$

Quae ${ }^{20}$ tanta erit ${ }^{21}$ gloriatio eius / passiones, ${ }^{22}$

ut pro qualitate uester exiguo ${ }^{23} /$ uestire deum meruit et uidere.

O animae / imitanda benignitas.

O uirtutum et ueneran $/ \mathrm{do}^{24}$ potentia. Sic egit suscepti pontificatus offi/cium, ut per formam probabilis < uitae> obseruantiae tuae / exierit ${ }^{25}$ disciplini. $^{26}$

Sic apostolicam uirtutem ${ }^{27}$ / operantibus contulit medicinam, ut alius ${ }^{28} /$ supplicationibus alius ${ }^{29}$ iusso saluaret.

$\mathrm{Haec}^{30}$ / tua domine ueneranda potentia cui merito / omnes angeli et archangeli ${ }^{31}$ non cessant clamare dicentes...

${ }^{1}$ contestatio] normally the prayer titles are rubrics; this one is in the same ink as the prayer texts. Additionally, the prefaces in other Masses all start directly with VD, and do not have a separate title ${ }^{2}$ te] add. rec. sup. lin. ${ }^{3}$ sancti] sanctae ante corr. ${ }^{4}$ spiritu] spiritui ante corr., i eras. sancto spiritu] intell. sancti spiritus ${ }^{5} \mathrm{ut}$ ] add. rec. sup. lin.; hypercorrect ${ }^{6}$ pauperem] intell. paupere ${ }^{7} \mathrm{ut}$ ] intell. et ${ }^{8}$ quam] add. rec. sup. lin., the original word (or the first two letters of the word) is erased ${ }^{9}$ egenus] egenos ante corr., the $\mathrm{u}$ is written through the $\left.\mathrm{o}{ }^{10} \mathrm{dominum}\right] \mathrm{dmm}$ with an abbreviation mark ${ }^{11}$ felix] filex ante corr. ${ }^{12}$ clamidis] clamides ante corr.

${ }^{13}$ quae] qu ante corr? e caudata addid. sup. lin. ${ }^{14}$ domum] intell. donum ${ }^{15}$ dignae] intell. digne ${ }^{16}$ dignia regionum] intell. digne Arrianorum ${ }^{17}$ ferritate] intell. feritati ${ }^{18}$ dignae] intell. digne ${ }^{19}$ saecuribus] intell. securus ${ }^{20}$ quae] intell. quia ${ }^{21}$ erit] intell. erat ${ }^{22}$ passiones] intell. passionis ${ }^{23}$ uester exiguo] intell. uestis exiguae ${ }^{24}$ uererando] intell. ueneranda ${ }^{25}$ exierit] intell. exigeret ${ }^{26}$ disciplini] intell. disciplinae; disciplinis ante corr., s eras. According to Dold \& Eizenhöfer it is the other way round; difficult to see ${ }^{27}$ apostolicam uirtutem] intell. apostolica uirtute ${ }^{28,29}$ alius] intell. alios ${ }^{30} \mathrm{haec}$ ] intell. hac ${ }^{31} \mathrm{et}$ archangeli] add. rec. sup. lin. 


\section{Gothic Missal, ed. by Rose, pp. 527-28}

IMMOLACIO Dignum et iustum est nos te, domine deus noster, in laudibus sancti Martini honorari. ${ }^{1}$

Qui sancti spiritus tui dono succensus ita in ipso tyrocinio fidei perfectus, ${ }^{2}$

ut Christum texissit ${ }^{3}$ in pauperem ${ }^{4}$ et uestem, quam egenus acceperat, mundi dominus induisset.

O filex ${ }^{5}$ largitas, qua diuinitas operitur.

O clamides ${ }^{6}$ gloriosa diuisio, quae militem texit et regem. Inaestimabile donum est, quod uestire deum $<247 \mathrm{r}>$ meruit deitatis.

Digne huic confessionis tuae praemium commisisti.

Digne Arrianorum non subiacuit feritate. ${ }^{7}$

Digne tanto amore Martinus persecutores ${ }^{8}$ tormenta non timuit securus,

quia tanta erat gloriacio passionis,

ut per $^{9}$ quantitate $^{10}$ uestis exiguae et uestire deum meruit et uidere.

$\mathrm{O}$ animi imitanda benignitas.

O uirtutum ueneranda potencia. Sic egit suscepti pontificatus officium, ut per formam probabilis ${ }^{11}$ uitae obseruanciam exegerit ${ }^{12}$ disciplinae.

Sic apostolica uirtute sperantibus contulit medicinam, ut alios supplicacionibus, alios uisu saluaret.

$\mathrm{Haec}^{13}$ tua, domine, ueneranda potencia, $\langle 247 \mathrm{v}\rangle$ cui cum lingua non supplet meritis exorare, operibus ${ }^{14}$ sancti Martini te opetulante ${ }^{15}$ mereamur imitari. Per Christum dominum nostrum.

${ }^{1}$ honorari] intell. honorare ${ }^{2}$ perfectus] perfectus inuentus est ${ }^{3}$ texissit] intell. texisset ${ }^{4}$ pauperem] intell. paupere ${ }^{5}$ filex] intell. felix ${ }^{6}$ clamides] intell. chlamydis ${ }^{7}$ feritate] intell. feritati ${ }^{8}$ persecutores] intell. persecutoris ${ }^{9}$ per] intell. pro or ${ }^{10}$ quantitate] intell. quantitatem ${ }^{11}$ probabilis] probalilis ante corr. cont. ${ }^{12}$ exegerit] intell. exigeret ${ }^{13}$ haec] intell. hac ${ }^{14}$ operibus] intell. opera ${ }^{15}$ opetulante] intell. opitulante

\begin{tabular}{|ll}
\hline Abbreviations & \\
add. (rec.) & additio (recentior) \\
addid. & addidit \\
ante corr. (cont./rec.) & ante correctionem (contemporaneam/recentiorem) \\
eras. & erasum est \\
intell. & intellige \\
sup. lin. & super lineam
\end{tabular}


The book is a pure sacramentary, offering Masses for the Sundays and feast days of the entire year, probably starting with Advent (though at the beginning four quires are missing so that the book starts in the middle of the Christmas vigil) and conflating the sanctoral part (with twenty-six Masses) with the temporal part. ${ }^{81}$ The Mass of Martin is found at the very end of the book as it is preserved - originally a number of quires followed, but these have been lost. The Mass, found between the Sunday Masses and general services for saints, was presumably added as a separate libellus. ${ }^{82}$

The Mass as it occurs in the Prague Sacramentary consists of four prayers, of which the first prayer and the contestatio correspond to the Gothic Missal. The second prayer, over the gifts, is in use in many of the Eighth-Century Gelasian sacramentaries as a general prayer for confessores. ${ }^{83}$ The fourth prayer, ad complendum, is found only in Prague. The most interesting text for the present discussion is the contestatio. This is a famous text, found first in the Gallican sacramentaries and then, in an adapted version, in all Eighth-Century Gelasian sacramentaries. Remarkably enough Prague does not follow the version of the Eighth-Century Gelasian sacramentaries, but the one found in the Old Gallican Mass books: the Gothic Missal and the Bobbio Missal. ${ }^{84}$ This older version is not without linguistic particularities, consisting mainly of deviant orthography and a few morphological anomalies, ${ }^{85}$ and these are included in Prague as well, partly corresponding with, partly deviating from the version in the Gothic Missal.

${ }^{81}$ See further on the book's content Missale Gothicum, ed. by Rose, pp. 20-22.

${ }^{82}$ Missale Gothicum, ed. by Leo Cunibert Mohlberg, Missale Gothicum (Vat. reg. lat. 317), Rerum ecclesiasticarum documenta, Series Maior, Fontes, 5 (Rome: Herder, 1961), p. xxv.

${ }^{83}$ E.g. Sacramentarium Engolismense, 1575; Sacramentarium Gellonense, 1709; Sacramentarium Sangallense, 1414. The context is mostly the natale of Pope Damasus.

${ }^{84}$ The Bobbio Missal is a composite manuscript, containing a sacramentary with lectionary, penance material, and other matters. It is supposed to have served as a book for a priest in a peripheral, non-urban environment. The book is dated to the first half of the eighth century and was probably written in south-east Gaul, but was found in the north Italian monastery of Bobbio, from which it derives its name. Missale Bobbiense, ed. by Elias A. Lowe, André Wilmart, and Henry A. Wilson, The Bobbio Missal: A Gallican Mass-Book, HBS, 53, 58, 59 (London: Henry Bradshaw Society, 1917-24); The Bobbio Missal: Liturgy and Religious Culture in Merovingian Gaul, ed. by Yitzhak Hen and Rob Meens (Cambridge: Cambridge University Press, 2004).

${ }^{85}$ For an annotated version of the text in the Gothic Missal, see Missale Gothicum, ed. by Rose, pp. 527-28. 
As far as the language of the famous prayer Qui sancti spiritus tui dono succensus is concerned, Prague and the Gothic Missal correspond literally in some irregularities, as Table 5 shows. Thus, in line 3 pauperem is given instead of paupere. The deviant orthography has a phonological background: since the final - $m$ was not perceived in pronunciation, it was omitted in writing. In line 4, an exchange of vowels has taken place in the word felix, also common for the Latin of the pre-Carolingian era. The original writing was fllex instead of felix, corrected in a contemporary hand. In line 5 , a correction is visible in the word clamidis, which was originally written as clamides, corrected by a later hand. The corrector(s) did not continue their emendation after the seventh line of the contestatio. In line 7 , ferritate is written where it should read feritati: a change of $-i$ and -e which has a phonological background. ${ }^{86}$ Apart from this, the intervocalic $\mathrm{r}$ is doubled in Prague, a duplication that does not occur in the Gothic Missal. In line 14, to conclude, haec is written where it should read hac.

Next to these parallels, Prague shows some textual deviations that do not occur in this text in the Gothic Missal but which are comparable to what generally happens in the Burgundian manuscript. Thus, in line 3, the ending of egenus was originally written egenos; the exchange of $-\mathrm{u}$ and -o in the first case masculine singular is a recurrent phenomenon in the Gothic Missal. ${ }^{87}$ The opposite, an ending on -us where it should be -os, occurs in line 13, twice in the word alius for alios. Numerous examples of this phenomenon can be found in the Gothic Missal. ${ }^{88}$ The writing of the ending of an adverb with -ae instead of -e (dignae in lines 6 and 8) is a common hypercorrection in the Latin of the early medieval period, and occurs as well in the Gothic Missal. ${ }^{89}$ Similarly, the ending of passiones in line 9, where a genitive singular is meant, is not uncommon..$^{90}$ The form exierit instead of exigeret in line 12 is complex, because it

86 The development of the Latin phonological system and its representation in writing, where the quantitative distinction between long and short vowels was gradually replaced by a qualitative distinction between open and closed vowels, is described by Veiko Väänänen, Introduction au latin vulgaire (Paris: Klincksieck, 1981), pp. 29-35, with a diagram on p. 30, and József Herman, Le latin vulgaire (Paris: Presses universitaires de France, 1967), chap. 4.

${ }^{87}$ Missale Gothicum, ed. by Rose, 152, 1. 7; 281, 1. 6; 296, 1. 6; 325, 1. 2; 381, 1. 2; 482, 1. 2; $540,1.4$.

${ }^{88}$ Missale Gothicum, ed. by Rose, 66, 1. 5; 220, 1. 5; 249, 1. 6 and 7; 332, 1. 5; 343, 1. 8; 409, 1. 4; 423, 1. 24; 468, 1. 2-3; 516, 1. 2; 532, 1. 5; 534, 1. 5 and 6.

${ }^{89}$ Missale Gothicum, ed. by Rose, 270, 1. 18.

${ }^{90}$ Missale Gothicum, ed. by Rose, 280, 1. 6; 317, 1. 6; 325, 1.3, and clamides in this immolacio, mentioned above. 
shows not only a loss of a voiced consonant between two vowels (a common process in the development from Latin to the Romance languages ${ }^{91}$ ) but also an exchange of $-e$ and $-i$ in the ending. ${ }^{92}$ The forms apostolicam uirtutem instead of apostolica uirtute in line 13 are comparable to pauperem in line 3 discussed above. There is one phenomenon of which only the reverse is testified in the Gothic Missal, namely the writing of $u t$ instead of $e t$ in lines 2 and 3. The opposite, et pro $u t$, occurs in five passages in the Gothic Missal. ${ }^{93}$

Finally, Prague shows irregularities for which no parallels are found in the Gothic Missal. The abbreviation dmm for dominum (line 3) and domum instead of donum in line 5 are both peculiar and probably reflect writing errors rather than linguistic (grammatical, orthographical, or phonological) change. The writing of dignia regionum where the Gothic Missal gives digne Arrianorum is as yet unsolved.

\section{Conclusion}

The analysis of the sanctoral cycle of the Prague Sacramentary highlights some important aspects that add to our knowledge and understanding of the book and its cultural context. The commemoration of the saints as practised in the circle that used the Prague Sacramentary outlines this document as a unique book, albeit with strong links to the surrounding liturgical traditions. In addition, it is an eclectic composition, making use of the main contemporary sacramentaries (Gregorian, Old Gelasian, and Eighth-Century Gelasian). More surprising is the fact that Prague reverts to traditions of an earlier century that stem from a different geographical region (Merovingian Gaul) in order to celebrate a special (patron) saint, St Martin.

Hammer's conclusion that the Prague Sacramentary was in use in a cult centre where Martin was venerated with special care is beyond doubt; the incorporation of the Mass for 4 July and the double Mass for his natale confirm this. Yet I do not follow Hammer ${ }^{94}$ and Dold and Eizenhöfer ${ }^{95}$ in their tendency to

91 Édouard Bourciez, Éléments de linguistique romane, 5th edn, Tradition de l'humanisme, 10 (Paris: Klincksieck, 1967), pp. 166-68; Missale Gothicum, ed. by Rose, 517, 1. 1.

${ }^{92}$ Missale Gothicum, ed. by Rose, 28, 1. 4; 152, 1. 15; 454, 1. 3.

93 Missale Gothicum, ed. by Rose, 158, 1. 4; 205, 1. 10; 318, 1. 2; 319, 1. 4; 349, 1. 3.

${ }^{94}$ Hammer: 'The Social Landscape', p. 46.

95 Das Prager Sakramentar, ed. by Dold and Eizenhöfer, p. 92. Dold and Eizenhöfer point to the Mass for Martin's translation as a 'Kronzeuge für eine Provenienz aus Tours'. The presence 
explain the predilection for Martin by a close relation of this cult centre with Tours. Martin was a universally celebrated saint and an important patron in the south German and north Italian region. This is visible in the presence of a special prefatio in the so-called Sacramentary of Salzburg, a Mass book composed around 800 and of north Italian origin, presumably in use in Padua, where the church of the martyr Justina was decorated with scenes from Martin's life. ${ }^{96}$ A specific link with Tours is not necessary to explain the presence of Masses in commemoration of Martin in the Prague Sacramentary - even though it is quite obvious that these links are likely to have existed. ${ }^{97}$

More revealing than the marked position of the great Gallic saint in the Prague Sacramentary is the relation to prayers from Merovingian Gaul for his commemoration, most specifically those appearing in the Missale Gothicum. Both language and content indicate that the composer(s) of the Prague Sacramentary knew the prayers for Martin as we know them through the Gallican sacramentaries (Gothic Missal, Bobbio Missal) and their eighth-century successors. The language employed in the contestatio for Martin in Prague seems to be much more comparable to the Gallican sacramentaries like the Gothic Missal than to the Frankish Eighth-Century Gelasian sacramentaries, Prague's contemporaries. Geographically speaking, there must have been some link or possibility of exchange between the composer(s) of Prague and the regions in which the Gallican sacramentaries were in use, that is, Burgundy or south-east Gaul. The evidence of an exchange between Prague and Frankish Gaul provided by the liturgical prayers in honour of St Martin is reinforced by the interest in the cult of the apostles and the narrative accounts of their

of a Mass for this feast in the Sacramentary of Angoulême indicates that Tours did not have the exclusive rights to special commemorations of Martin. The same goes for the contestatio: this Mass does contain much material from Sulpicius's Vita Martini, but the text was at the same time so widely spread (Bobbio Missal, Gothic Missal) that we do not have to rely on Tours to find a link with Prague.

96 Sacramentary of Salzburg, ed. by Alban Dold and Klaus Gamber, Das Sakramentar von Salzburg seinem Typus nach auf Grund der erhaltenen Fragmente rekonstruiert in seinem Verhältnis zum Paduanum untersucht, Beiträge zur Ergründung des älteren lateinischen christlichen Schrifttums und Gottesdienstes, 4 (Beuron in Hohenzollern: Beuroner Kunstverlag, 1960), Introduction, p. 3. This prefatio is a remarkable text, not in accordance with any of the known hagiographic traditions, and in places even at odds with Sulpicius's Vita. Details in Els Rose, 'In laude sancti Martini' (unpublished master's thesis, Utrecht University, 2001), pp. 129-31.

${ }^{97}$ See for example Bauerreiß's reference to the friendship between Arn of Salzburg and Alcuin. Das Prager Sakramentar, ed. by Dold and Eizenhöfer, pp. 42-43. 
lives and passions shared by both regions. The earliest manuscripts containing the Virtutes apostolorum date to roughly the same period as the Prague Sacramentary and occur both in Bavaria and in Frankish Gaul.

Language remains an important tool for further study of the Prague Sacramentary. The linguistic particularities in the contestatio for Martin in the Gothic Missal and the Prague Sacramentary are on the whole of the same nature. Culturally speaking, then, Prague must be classified among those textual testimonies of the eighth century that were highly influenced by colloquial language, and largely escaped the revising hand of the Carolingian language reforms. ${ }^{98}$ To be sure, a corrector took away some of the grammatical deviations, but only in part - was it too much to complete the work? The study of the language of only one text raises more questions than it can answer. However, Dold's suggestion that we are dealing with a hearing-impaired scribe seems to be an insufficient explanation. ${ }^{99}$

${ }^{98}$ See Das Prager Sakramentar, ed. by Dold and Eizenhöfer, pp. 89-90.

${ }^{99}$ Das Prager Sakramentar, ed. by Dold and Eizenhöfer, pp. 83-89; Gamber, 'Das TassiloSakramentar in Prague', p. 17. 